https://www.journal-imab-bg.org

Case reports

\title{
VARICELLA ZOSTER VIRUS ASSOCIATED ASEPTIC MENINGITIS IMMUNOCOMPETENT PATIENT \\ IN AN
}

\author{
Zhivka Stoykova ${ }^{1,2}$, Tsvetelina Kostadinova ${ }^{1,3}$, Radka Argirova ${ }^{4}$ \\ 1) Laboratory of Virology," St. Marina” University Hospital - Varna, Bulgaria \\ 2) Department of Microbiology and Virology, Medical University of Varna, \\ Bulgaria \\ 3) Medical College, Medical University of Varna, Bulgaria \\ 4) Clinical Laboratory, Acibadem City Clinic Tokuda Hospital, Sofia, Bulgaria..
}

\section{ABSTRACT}

BACKGROUND: Varicella zoster virus (VZV) is a widespread herpes virus that causes chickenpox after primary infection. Later the virus remains persistent in the sensory nerve ganglia, and it can be reactivated with the manifestation of herpes zoster most often. But reactivation of VZV can manifest as infection of the CNS (central nervous system) even in an immunocompetent host. The detection of VZV $\mathrm{Ab}$ by ELISA and VZV-DNA in cerebrospinal fluid by PCR has improved the laboratory conformation of that condition in an immunocompetent host with discreet exanthema.

MATERIAL AND METHODS: Two serum samples and three CSF samples of a patient with aseptic meningitis were tested by ELISA and PCR.

INTERPRETATION: This clinical case demonstrates that VZV may be considered in all cases of aseptic meningitis even in immunocompetent individuals without the typical rash. In cases under VZV associated meningitis suspicion, the first detection marker to be positive is VZV-DNA and later anti-VZV IgG in CSF.

Keywords: VZV, VZV reactivation, VZV-DNA in $\mathrm{CSF}$, aseptic meningitis,

\section{INTRODUCTION}

Varicella zoster virus (VZV) is a widespread alpha herpes virus that causes chickenpox after primary infection. Later the virus remains persistent in the sensory nerve ganglia, and when the specific cell mediated immunity is weakened, it can be reactivated with the manifestation of herpes zoster most often. VZV reactivation can also cause a wide range of neurological diseases that may affect the central nervous system (CNS) [1]. VZV reactivates mostly in elderly and immune-compromised patients. Meningitis is considered a rare complication of the latent infection, especially in previously healthy individuals [2]. Etiologically strictly, aseptic meningitis in healthy individuals more often is due to other viruses. In a study performed with PCR analysis from CSF among 144 immunocompetent aseptic meningitis patients in Finland, the largest proportion (26\%) was with enteroviral etiology, followed by HSV-2 (17\%) and third place for VZV etiology with 8\% [3]. Similar results have been reported in Turkey among 33 patients with aseptic meningitis [4]. The incidence of central nervous system VZV infections varies from $5 \%$ to $29 \%$, and their significance is determined by the serious complications that may follow $[5,6]$. This determines the need for a prompt diagnostic method that provides adequate therapy.

\section{MATERIALS AND METHODS:}

\section{Material:}

Two serum samples and three CSF samples of a patient with aseptic meningitis.

\section{Methods:}

Serology: Commercial ELISA test kits for detection of anti VZV IgM/IgG, EUROIMMUN, Germany.

PCR: Multiplex PCR (FTD, Fasttrack Diagnostics, Luxembourg) detecting 11 viruses in serum/ CSF simultaneously (EBV, CMV, VZV, HSV-1, HSV2, HHV-6, HHV-7, Adenovirus - AV, Enterovirus EV, Parechovirus and Parvovirus B19)

\section{CASE PRESENTATION:}

We present a clinical case of a young 42 years old immunocompetent woman who develops aseptic meningitis after VZV reactivation with the appearance of a discreet vesicular rash of herpes zoster type. 
She was diagnosed with chickenpox two years ago. The present onset of the disease is acute, presented with common malaise, twice vomiting and subfebrile temperature $\left(37.4^{\circ} \mathrm{C}\right)$. The clinical presentation after five days is complemented with headache, nausea, and back pain that radiates to the neck. A discreet rash appears at the site of the pain in the back and abdomen along the nerve on the next day. The patient is hospitalized the next day. From the objective status - impaired general condition, intoxicated, afebrile at the time of the examination, pale skin with reduced turgor, in the area of the left Th10-Th12 dermatom - vesicular rash, peripheral lymph nodes not enlarged. The microbiological analysis did not detect any bacteria in hemocultures, CSF and urine. A resident flora is isolated from the nose/throat swap. Given the clinical presentation, empirical therapy with Aciclovir p.o. at a maximum dose of $5 \times 800 \mathrm{mg} / \mathrm{d}$ for 21 days, and $10 \mathrm{mg} /$ day $10 \%$ Mannitol infusions $3 \times 200 \mathrm{ml} / \mathrm{d}$ of as well as symptomatic therapy was promptly started.

In the course of hospitalization, specific antiVZV antibodies (Euroimmun, Germany) levels were examined both in serum (a total of 2 samples) and CSF (a total of 3 samples). VZV-DNA was tested and detected only in the first CSF sample, and anti-VZV IgG was detected in the second and third CSF samples. The control serum sample taken one month after the acute onset of the disease showed approximately a 17 -fold increase in titer of the specific VZV Ab (Tab.1). Clinical laboratory tests of CSF strongly suggest and point to aseptic meningitis (Tab.2). Following the treatment, the patient recovered completely.

Tab.1. Results of virological tests of serum and CSF in chronological order.

\begin{tabular}{|c|c|c|c|c|c|c|c|c|c|}
\hline & $\begin{array}{l}\text { VZV- } \\
\text { DNA } \\
\text { (PCR) }\end{array}$ & $\begin{array}{l}\text { Anti } \\
\text { VZV } \\
\text { IgM }\end{array}$ & $\begin{array}{l}\text { Anti VZV } \\
\text { IgG }(+)>110 \\
\text { IU/L }\end{array}$ & \begin{tabular}{|l} 
Anti \\
HSV1 \\
IgG
\end{tabular} & $\begin{array}{l}\text { Anti } \\
\text { HSV2 } \\
\text { IgG }\end{array}$ & $\begin{array}{l}\text { Anti } \\
\text { Adenovirus } \\
\operatorname{IgG}(+)> \\
22 \mathrm{RU} / \mathrm{ml}\end{array}$ & $\begin{array}{l}\text { Anti } \\
\text { Enterovirus } \\
\text { IgG }(+)>1,1 \mathrm{R}\end{array}$ & $\begin{array}{l}\text { Anti } \\
\text { Influenza A } \\
\operatorname{IgG}(+)> \\
22 \mathrm{RU} / \mathrm{ml}\end{array}$ & $\begin{array}{l}\text { Anti Influenza } \\
\text { B IgG }(+)> \\
22 \mathrm{RU} / \mathrm{ml}\end{array}$ \\
\hline $\begin{array}{l}17.10 .18 \\
\text { Serum } 1\end{array}$ & & $\mathrm{Neg}$ & $453 \mathrm{IU} / \mathrm{L}$ & - & - & - & - & - & - \\
\hline $\begin{array}{l}17.10 .18 \\
\text { CSF } 1\end{array}$ & Pos & Neg & $\mathrm{Neg}$ & Neg & Neg & Neg & Neg & - & - \\
\hline $\begin{array}{l}30.10 .18 \\
\text { CSF } 2\end{array}$ & & Neg & $491 \mathrm{IU} / \mathrm{L}$ & Neg & $\mathrm{Neg}$ & Neg & Neg & $\mathrm{Neg}$ & Neg \\
\hline $\begin{array}{l}6.11 .18 \\
\text { CSF } 3 \\
\end{array}$ & & Neg & 366 IU/L & Neg & $\mathrm{Neg}$ & Neg & Neg & $\mathrm{Neg}$ & $\mathrm{Neg}$ \\
\hline $\begin{array}{l}22.11 .18 \\
\text { Serum } 2\end{array}$ & & $\mathrm{Neg}$ & $7634 \mathrm{IU} / \mathrm{L}$ & Neg & - & $118 \mathrm{RU} / \mathrm{ml}$ & $1,11 \mathrm{R}$ & $112 \mathrm{RU} / \mathrm{ml}$ & $184 \mathrm{RU} / \mathrm{ml}$ \\
\hline
\end{tabular}

Tab.2. Results of clinical laboratory tests of CSF.

\begin{tabular}{|l|l|l|l|}
\hline TEST & \multicolumn{2}{l|}{ CSF 1 } & \multicolumn{2}{l|}{ CSF 2 3} \\
\hline common & $\begin{array}{l}\text { clear liquor, under gentle } \\
\text { pressure }\end{array}$ & $\begin{array}{l}\text { clear liquor, under normal } \\
\text { pressure }\end{array}$ & $\begin{array}{l}\text { clear liquor, under normal } \\
\text { pressure }\end{array}$ \\
\hline Pandy & + & - & - \\
\hline Rivalta & - & - & - \\
\hline Er & 0 per $\mu \mathrm{l}$ & 0 per $\mu \mathrm{l}$ & 0 per $\mu \mathrm{l}$ \\
\hline Leu & $341 \mathrm{per} \mu \mathrm{l}$ & $81 \mathrm{per} \mu \mathrm{l}$ & $26 \mathrm{per} \mu \mathrm{l}$ \\
\hline Glucose & $3,5 \mathrm{millimoles} /$ liter & $3,5 \mathrm{millimoles} \mathrm{/} \mathrm{liter}$ & $3,2 \mathrm{millimoles} \mathrm{/} \mathrm{liter}$ \\
\hline Protein & $1,62 \mathrm{~g} / \mathrm{l}$ & $0,38 \mathrm{~g} / \mathrm{l}$ & $0,23 \mathrm{~g} / \mathrm{l}$ \\
\hline Chlorides & 118 millimoles / liter & 120 millimoles / liter & 123 millimoles / liter \\
\hline Sediment & $99,8 \%$ mononuclears & $100 \%$ mononuclears & $100 \%$ mononuclears \\
& $0,2 \%$ polymorphonuclears & & \\
\hline
\end{tabular}




\section{DISCUSSION:}

The presented a case of VZV associated aseptic meningitis in a young immunocompetent woman was proven by clinical, virological and serological data. The diagnosis of VZV associated aseptic meningitis is very likely due to the clinical presentation supplemented with the discrete, but typical herpes zoster rash accompanying the neurological symptoms. In this case, the presence of a rash supports the clinical diagnosis, but there are described cases without rash in the literature [7]. Additionally, the disease develops shortly after primary infection ( 2 years ago) at the background of a relatively low serum antibody titres, which we assume may be the cause of VZV viremia that has led to meningitis.

The specific treatment options for VZV associated meningitis require an adequate laboratory confirmation of the etiology. Relatively low anti-VZV antibody titer was found in the serum of the patient at the onset of the disease (anti-VZV IgG (+) $453 \mathrm{IU} / \mathrm{L}>$ $110 \mathrm{IU} / \mathrm{L}$, positive), no specific antibodies were found in the CSF sample taken at the same time. In addition, using qualitative multiplex PCR, VZV-DNA was detected in this first CSF sample, with a negative result for ten other viruses commonly associated with aseptic meningitis (EBV, CMV, HSV-1, HSV-2, HHV6, HHV-7, Adenovirus, Enterovirus, Parechovirus and Parvovirus B19). PCR analysis of CSF has revolutionized the diagnosis of nervous system viral infections, particularly those caused by human herpesviruses. PCR analysis has now replaced brain biopsy as the gold standard for the diagnosis of herpes simplex virus encephalitis [8]. We believe that the diagnosis is quite certain due to the detection of anti VZV IgG antibodies in the CSF sample taken two weeks after the acute onset of the disease (Tab. 1). The presence of a strong intrathecal anti VZV IgG production confirmed the VZV etiology of the infection in the CNS. Upon re-examination of the CSF one week later, the $\mathrm{Ab}$ continued to persist, although in a decreasing titre (Tab. 1). Other authors also detect antibodies in CSF due to their intrathecal production [7]. On the other hand, detection of anti VZV Ab in CSF is considered to be a more sensitive method than the detection of VZV-DNA in the aspect of the confirmation of VZV etiology in vasculitis and the authors consider that a negative PCR result does not exclude the diagnosis [9]. This is probably due to the time of sampling for the two methods. Our results show that PCR is a more sensitive method in the first days after the onset of symptoms, whereas virus specific antibodies in CSF appear later - two weeks after the onset. In the absence of PCR analysis, the serology tests should be performed more frequently and not too early, in order to escape false negative results. Since lumbar puncture is an invasive procedure, we believe that the serum anti VZV IgG titer can also be tracked. In one study the presence of detectable VZV antibodies in CSF measured by indirect immunofluorescence seemed to correlate with clinical evidence of central nervous system involvement due to VZV [10].

\section{CONCLUSION:}

This clinical case demonstrates that VZV may be considered in all cases of aseptic meningitis in immunocompetent individuals, even in cases with discreet exanthema. It may increase the intracranial pressure, leading to symptoms, and causing the reversible neurological deficit. Rapid virologic verification and prompt treatment with antiviral agents can lead to complete recovery.

Disclosure Statement: The authors report no conflict of interest.

\section{REFERENCES:}

1. Mueller NH, Gilden DH, Cohrs RJ, Mahalingam R, Nagel MA. Varicella zoster virus infection: clinical features, molecular pathogenesis of disease and latency. Neurologic Clinics. 2008 Aug;26(3):675-97. [PubMed][Crossref]

2. Gupta P, Ranjan R, Agrawal CS, Muralikrishnan K, Dave N, Rana DS. Meningitis with polymerase chain reaction for varicella zoster positivity in cerebrospinal fluid of a young immunocompetent adult. J Neurosci Rural
Pract. 2016; 7(4):591-593. [Crossref]

3. Kupila L, Vuorinen T, Vainionpaa R, Hukkanen V, Marttila RJ, Kotilainen P. Etiology of Aseptic Meningitis and Encephalitis in an Adult Population. Neurology. 2006 Jan 10;66(1):75-80. [PubMed] [Crossref]

4. Kahraman H, Tünger A, Senol S, Gazi H, Avci M, Örmen B, et al. [Investigation of Bacterial and Viral Etiology in Community Acquired Central Nervous System Infections With Molecular Methods] [in Turkish]
Mikrobiyol Bul. 2017 Jul;51(3):277285. [PubMed] [Crossref]

5. Koskiniemi M, Rantalaiho T, Piiparinen $\mathrm{H}$, von Bonsdorff $\mathrm{CH}$, Färkkilä M, Järvinen A, et al. Infections of the central nervous system of suspected viral origin: a collaborative study from Finland. J Neurovirol. 2001 Oct;7(5):400-8.[PubMed][Crossref]

6. Frantzidou F, Kamaria F, Dumaidi K, Skoura L, Antoniadis A, Papa A. Aseptic Meningitis and Encephalitis Because of Herpesviruses 
and Enteroviruses in an Immunocompetent Adult Population. Eur J Neurol. 2008 Sep;15(9):995-7. [PubMed] [Crossref]

7. Pasedag $\mathrm{T}$, Weissenborn $\mathrm{K}$, Wurster U, Ganzenmueller T, Stangel M, Skripuletz T. Varicella Zoster Virus meningitis in a young immunocompetent adult without rash: A Misleading Clinical Presentation. Case Reports in Neurological Medicine. 2014;
2012:686218. [PubMed] [Crossref]

8. DeBiasi RL, KleinschmidtDeMasters BK, Weinberg A, Tyler KL. Use of PCR for the Diagnosis of Herpesvirus Infections of the Central Nervous System. J Clin Virol. 2002 Jul;25(Suppl 1):S5-11. [PubMed] [Crossref] . Nagel MA, Forghani B, Fluid. J Clin Microbiology. 1980

Mahalingam R, Wellish MC, Cohrs RJ, Dec;12(6):764-7. [PubMed] [Crossref] tecting anti-VZV IgG antibody in CSF to diagnose VZV vasculopathy. Neurology. Mar 2007 Mar;68(13):106973. [PubMed] [Crossref]

10. Gershon A, Steinberg S, Greenberg S, Taber L. Varicella-ZosterAssociated Encephalitis: Detection of Specific Antibody in Cerebrospinal

Please cite this article as: Stoykova Z, Kostadinova T, Argirova R. Varicella zoster virus associated aseptic meningitis in an immunocompetent patient. J of IMAB. 2020 Apr-Jun;26(2):3053-3056.

DOI: https://doi.org/10.5272/jimab.2020262.3053

Received: 24/06/2019; Published online: 02/04/2020

\section{Corresponding author:}

Zhivka Stoykova

Laboratory of Virology, University Hospital St. Marina, Varna

1, Hristo Smirnenski Blvd., 9010, Varna, Bulgaria

E-mail: jivita77@abv.bg, 